\title{
Tuberculosis and lactic acidosis as causes of death in adult patients from a regional hospital in Johannesburg
}

\author{
Authors: \\ Malangu Ntambwe ${ }^{1}$ \\ Mogashoa Maryet ${ }^{2}$ \\ Affiliations: \\ ${ }^{1}$ Department of \\ Epidemiology, University of \\ Limpopo (Medunsa Campus), \\ South Africa \\ ${ }^{2}$ Center for Diseases Control, \\ South Africa

\section{Correspondence to:} \\ Malangu Ntambwe \\ Email: \\ gustavmalangu@gmail.com \\ Postal address: \\ PO Box 215, Medunsa 0204, \\ South Africa \\ Dates: \\ Received: 23 Dec. 2010 \\ Accepted: 22 Aug. 2011 \\ Published: 17 Feb. 2012 \\ How to cite this article: \\ Malangu N, Mogashoa \\ $M$. Tuberculosis and lactic \\ acidosis as causes of death in \\ adult patients from a regional \\ hospital in Johannesburg. \\ Afr J Prm Health Care Fam \\ Med. 2012;4(1), Art. \# 266, \\ 5 pages. http://dx.doi. \\ org/10.4102/phcfm.v4i1.266
}

(C) 2012. The Authors. Licensee: AOSIS OpenJournals. This work is licensed under the Creative Commons Attribution License.
Background: Tuberculosis and adverse effects have been shown to affect both the quality of life and the survival of patients on antiretroviral treatment. This study sought to investigate the causes of death in a sample of adult HIV-infected patients on antiretroviral treatment at Thembisa Hospital, Johannesburg, South Africa.

Methods: A retrospective study was conducted by examining the charts of 498 adult patients treated from January 2004 to December 2006 at the antiretroviral clinic of a regional hospital in Johannesburg. A data collection form was used to collate both sociodemographic and clinical data.

Results: The majority of the patients were female (71.7\%) with a mean age of $37.7 \pm 11.6$ years, and in the age group of 18-77 years. The greater number of the patients was South African citizens, with only 2.2\% citizens of other Southern African countries. At baseline, $29.9 \%$ had been on anti-tuberculosis treatment. Most of the patients had been prescribed the regimen comprising stavudine, lamivudine, and nevirapine or efavirenz; two of them $(0.4 \%)$ were on the second line regimen made of zidovudine, didanosine, and lopinavir-ritonavir. At least one side effect was documented in $82.1 \%$ of patients; the ten most documented side effects were skin rashes $(62.9 \%)$, peripheral neuropathy $(48.4 \%)$, headaches $(38.2 \%)$, chest pain $(21.9 \%)$, coughing $(21.7 \%)$, anaemia $(21.5 \%)$, diarrhoea $(19.3 \%)$, vomiting $(16.7 \%)$, dizziness $(15.3 \%)$, and lactic acidosis (11.2\%). A mortality rate of $3.6 \%$ was recorded during the 2 -year study period. Although the cause of death was undetermined in $11.1 \%$ of patients, $50.0 \%$ and $38.9 \%$ of deaths respectively were a consequence of tuberculosis and lactic acidosis.

Conclusions: In addition to tuberculosis, side effects in particular, lactic acidosis was the other main cause of death in patients treated at the study site. These findings suggest that patients on regimens containing drugs that cause lactic acidosis should be closely monitored when the first complaints suggesting lactic acidosis are reported or noticed.

La tuberculose et l'acidose lactique comme causes de décès de patients adultes d'un hôpital régional à Johannesburg

Contexte: Il a été prouvé que la tuberculose et ses effets négatifs affectaient à la fois la qualité de vie et la survie des patients sous traitement antirétroviral. Cette étude a cherché à enquêter sur les causes de décès d'un échantillon de patients adultes séropositifs sous traitement antirétroviral à l'hôpital de Thembisa, à Johannesburg, en Afrique du Sud.

Méthodes: Une étude rétrospective a été réalisée en examinant les carnets de santé de 498 patients adultes traités de janvier 2004 à décembre 2006 dans un centre de traitement antirétroviral d'un hôpital régional à Johannesburg. Un formulaire de collecte des données a été utilisé afin de recueillir des données sociodémographiques et cliniques.

Résultats: La majorité des patients étaient des femmes (71.7\%), dont la moyenne d'âge était de $37.7 \pm 11.6$ ans et qui appartenaient à la tranche d'âge des 18-77 ans. La majorité des patients étaient citoyens sud-africains, 2.2\% seulement étant des ressortissants d'autres pays d'Afrique australe. Au début de l'étude, $29.9 \%$ avaient suivi un traitement contre la tuberculose. La plupart des patients s'étaient vus prescrire le traitement à base de stavudine, lamivudine, et névirapine ou d'éfavirenz ; deux d'entre eux suivaient le traitement de seconde ligne à base de zidovudine, didanosine, et lopinavir-ritonavir. Un effet secondaire au moins a été documenté chez $82.1 \%$ des patients ; les dix effets secondaires les plus documentés étaient les éruptions cutanées (62.9\%), la neuropathie périphérique $(48.4 \%)$, les maux de tête (38.2\%), les douleurs thoraciques $(21.9 \%)$, la toux $(21.7 \%)$, l'anémie $(21.5 \%)$, la diarrhée $(19.3 \%)$, les vomissements $(16.7 \%)$, les vertiges $(15.3 \%)$ et l'acidose lactique (11.2\%). Un taux de mortalité de 3.6\% a été enregistré au cours de la période d'étude de deux ans. Bien que la cause du décès soit restée indéterminé pour $11.1 \%$ des patients, $50.0 \%$ et $38.9 \%$ des décès étaient respectivement dus à la tuberculose et à l'acidose lactique.

Conclusion: Outre la tuberculose, les effets secondaires, en particulier l'acidose lactique, étaient l'autre cause principale de décès chez les patients traités sur le site de l'étude. Ces conclusions indiquent que les patients suivant un traitement contenant des médicaments qui provoquent une acidose lactique doivent être suivis de près lorsque les premiers signes suggérant une acidose lactique sont signalés ou observés. 


\section{Introduction}

The roll-out of antiretroviral treatment in South Africa has led to positive outcomes that have been documented in several studies., ${ }^{1,2,3}$ Significant reductions in AIDS-related morbidity and mortality have been documented already. $4,5,6$ Unfortunately, up to $25 \%$ of patients discontinue their initial antiretroviral treatment regimen because of treatment failure, non-compliance or low adherence, as well as to adverse effects. ${ }^{7,8,9,10}$ Adverse effects have been shown to affect both the quality of life and the survival of patients, and it follows that it is important to describe these effects. In doing so, the findings of this study will contribute to the identification of adverse or side effects that should be targeted for monitoring by clinicians and for creating awareness of these effects amongst patients. The purpose of this study, therefore, was to investigate the causes of death in a sample of adult HIVinfected patients on antiretroviral treatment at Thembisa Hospital in Johannesburg, South Africa.

\section{Significance of the study}

This study investigated the side effects associated with mortality in a sample of adult HIV-infected patients on antiretroviral treatment. The findings of this study will contribute to the identification of side effects that should be targeted for monitoring by clinicians and for creating awareness of these effects amongst patients.

\section{Ethical considerations}

The approval to conduct this study was obtained from the Medunsa Campus Research and the Ethics Committee of the University of Limpopo. Permission to access the patients' records was requested and obtained from Management at the hospital.

\section{Methods}

A retrospective study was conducted by examining the charts of 498 adult patients treated from January 2004 to December 2006 at the antiretroviral clinic of a regional hospital in Johannesburg. A data collection form was used to collate both sociodemographic and clinical data, including the age and sex of the patients as well as the documented side effects, whether they had died or were still alive, the recorded cause of death, the stage of the infection, the duration of treatment, and the regimen they took. Descriptive statistics and crosstabulation were used in the analysis of data. All statistical analyses were performed using SPSS software (version 17.0; SPSS, Chicago, IL, USA).

\section{Results}

The sample comprised mostly female patients (71.7\%), whose mean age was $37.7 \pm 11.6$, ranging from 18 to 77 years. The greater number of the patients was South African citizens, with only $2.2 \%$ citizens of other Southern African countries such as the Democratic Republic of Congo (1), Malawi (1), Mozambique (1), Zambia (1), and Zimbabwe (7). The majority of patients had completed a high school level of education
TABLE 1: Sociodemographic and baseline data of HIV-infected patients from Thembisa Hospital 2004-2006.

\begin{tabular}{|c|c|c|}
\hline Variables & Frequency & $\%$ \\
\hline \multicolumn{3}{|l|}{ Gender } \\
\hline Female & 354 & 71.1 \\
\hline Male & 144 & 28.9 \\
\hline \multicolumn{3}{|l|}{ Age group (years) } \\
\hline $18-29$ & 70 & 14.1 \\
\hline $30-39$ & 244 & 49.0 \\
\hline $40-49$ & 134 & 26.9 \\
\hline $50+$ & 50 & 10.0 \\
\hline \multicolumn{3}{|l|}{ Level of education } \\
\hline Grades 0-7 & 108 & 21.7 \\
\hline Grades 8-12 & 374 & 75.1 \\
\hline Tertiary level & 16 & 3.2 \\
\hline \multicolumn{3}{|l|}{ Employment status } \\
\hline Unemployed & 400 & 80.3 \\
\hline Employed & 98 & 19.7 \\
\hline \multicolumn{3}{|l|}{ Lifestyle } \\
\hline Alcohol drinking status & 40 & 8.0 \\
\hline Smoking status & 34 & 6.8 \\
\hline \multicolumn{3}{|l|}{ Type of regimen } \\
\hline Regimen 1a & 312 & 62.7 \\
\hline Regimen $1 \mathrm{~b}$ & 184 & 36.9 \\
\hline Second line & 2 & 0.4 \\
\hline \multicolumn{3}{|c|}{ Tuberculosis (TB) treatment status } \\
\hline On TB treatment & 105 & 29.9 \\
\hline Not on TB treatment & 246 & 70.1 \\
\hline \multicolumn{3}{|l|}{ WHO clinical stage } \\
\hline Stage 1 & 45 & 9.0 \\
\hline Stage 2 & 169 & 33.9 \\
\hline Stage 3 & 239 & 48.0 \\
\hline Stage 4 & 45 & 9.0 \\
\hline \multicolumn{3}{|c|}{ Viral load (VL) status at baseline } \\
\hline$V L \leq 400$ & 8 & 1.6 \\
\hline$V L>400$ & 478 & 98.4 \\
\hline \multicolumn{3}{|c|}{ CD4 count status at baseline } \\
\hline CD4 > 200 & 14 & 2.8 \\
\hline $\mathrm{CD} 4 \leq 200$ & 484 & 97.2 \\
\hline
\end{tabular}

Source: Authors' original data

WHO, World Health Organisation.

TABLE 2: Side effects documented in HIV-infected patients at Thembisa Hospital 2004-2006.

\begin{tabular}{lcc}
\hline Side effects & Frequency & \% \\
\hline Skin rashes, itching & 313 & 62.9 \\
Peripheral neuropathy & 241 & 48.4 \\
Headache & 190 & 38.2 \\
Chest pains & 109 & 21.9 \\
Coughing & 108 & 21.7 \\
Anaemia & 107 & 21.5 \\
Diarrhoea & 96 & 19.3 \\
Nausea or vomiting & 83 & 16.7 \\
Dizziness & 76 & 15.3 \\
Lactic acid acidosis & 56 & 11.2 \\
Heartburn & 44 & 8.8 \\
Fatigue & 42 & 8.4 \\
Loss of appetite & 40 & 8.0 \\
Bloating & 38 & 7.6 \\
Weight loss & 37 & 7.4 \\
Muscle and joint pains & 33 & 6.6 \\
Trouble sleeping & 25 & 5.0 \\
Ringing in ear & 20 & 4.0 \\
Blurred vision & 20 & 4.0 \\
Cotrimoxazole allergy & 18 & 3.6 \\
\hline Source:Author' & &
\end{tabular}

Source: Authors' original data 
TABLE 3: Clinical stage of HIV-infected patients that died at Thembisa Hospital 2004-2006.

\begin{tabular}{|c|c|c|c|c|c|c|}
\hline \multirow[t]{2}{*}{ Period } & \multirow[t]{2}{*}{ Cause } & \multirow[t]{2}{*}{ Variables } & \multicolumn{2}{|c|}{ WHO stage } & \multicolumn{2}{|c|}{ Baseline CD4 counts values } \\
\hline & & & Stage 3 & Stage 4 & $\mathrm{CD} 4<100$ & CD4 100-200 \\
\hline \multirow[t]{11}{*}{ 6th-12th month } & Unknown & Patient 1 & Yes & - & 6 & - \\
\hline & & Patient 2 & Yes & - & - & 100 \\
\hline & Lactic acidosis & Patient 1 & - & Yes & 31 & - \\
\hline & & Patient 2 & Yes & - & - & 131 \\
\hline & Tuberculosis & Patient 1 & Yes & - & - & 193 \\
\hline & & Patient 2 & Yes & - & - & 196 \\
\hline & & Patient 3 & - & Yes & 1 & - \\
\hline & & Patient 4 & - & Yes & 9 & - \\
\hline & & Patient 5 & Yes & - & 38 & - \\
\hline & & Patient 6 & Yes & - & - & 169 \\
\hline & & Patient 7 & Yes & - & 71 & - \\
\hline \multirow[t]{5}{*}{ 12th-18th month } & Lactic acidosis & Patient 1 & Yes & - & 3 & - \\
\hline & & Patient 2 & Yes & - & 16 & - \\
\hline & & Patient 3 & Yes & - & - & 130 \\
\hline & Tuberculosis & Patient 1 & - & Yes & 85 & - \\
\hline & & Patient 2 & Yes & - & 84 & - \\
\hline 18th-24th month & Lactic acidosis & Patient 1 & - & Yes & 31 & - \\
\hline
\end{tabular}

$(75.1 \%)$ and were unemployed $(80.3 \%)$. With regard to their lifestyle, few of them smoked $(6.7 \%)$, or consumed alcoholic drinks (8\%). From the onset of enrolment into the antiretroviral treatment, $29.9 \%$ had been on anti-tuberculosis treatment.

Their immunological status was considered as poor because most of them $(97.2 \%)$ had CD4 counts $<200$ copies $/ \mathrm{mL}$. The majority $(57 \%)$ of them were afflicted by severe immune depression because they met the WHO (World Health Organisation) clinical Stage 3 and Stage 4. Most of the patients had been prescribed the regimen made of stavudine, lamivudine, and nevirapine or efavirenz; two of them $(0.4 \%)$ were on the second line regimen made of zidovudine, didanosine, and lopinavir-ritonavir (Table 1). At least one side effect was documented in $82.1 \%$ of patients. The ten most documented side effects (Table 2) were skin rashes $(62.9 \%)$, peripheral neuropathy $(48.4 \%)$, headaches $(38.2 \%)$, chest pain $(21.9 \%)$, coughing $(21.7 \%)$, anaemia $(21.5 \%)$, diarrhoea (19.3\%), vomiting (16.7\%), dizziness $(15.3 \%)$, and lactic acidosis (11.2\%). Of these side effects, lactic acidosis was associated with a number of deaths. Overall, a mortality rate of $3.6 \%$, or 18 deaths during the 2-year study period, was recorded. Although the cause of death was undetermined in $11.1 \%$ of patients, $50.0 \%$ and $38.9 \%$ of deaths were ascribed in the patients' records, respectively to tuberculosis and lactic acidosis (Figure 1). The odd ratios of dying from lactic acidosis was 5.6 [(95\% CI: $2.1-15.1) ; p=0.0001]$; compared to 4 [(95\% CI: $1.5-10.4) ; p=0.002]$ for tuberculosis. However, all the 18 patients that died were amongst the 284 that had severe immune suppression. Moreover, 11 of the 18 deaths had a CD4 cells count $\leq 100$ copies $/ \mathrm{mL}$ (Table 3 ). Although most of the deaths occurred between the first 6 months to the end of the first year of treatment (Figure 3), deaths associated with lactic acidosis continued to occur even after 18 months on treatment (Figure 4). Of those who died, the majority had been initiated on antiretroviral treatment late (they were classified as WHO Stage 3), they were mostly female, and aged 30-39 (Figure 2).

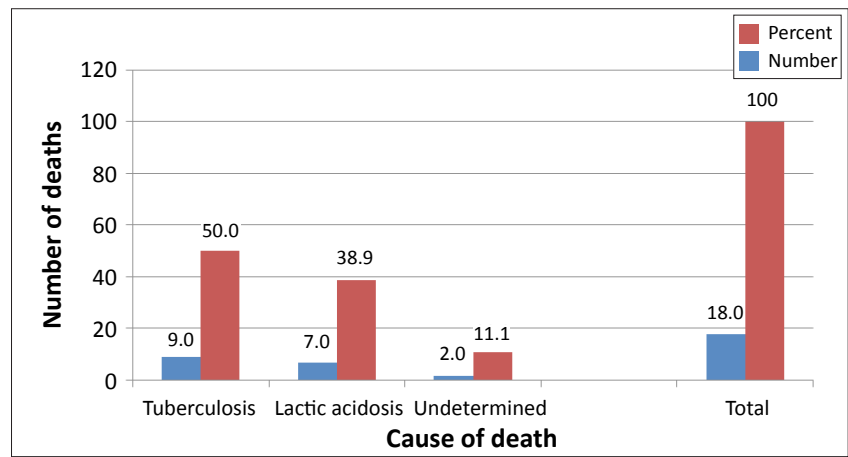

Source: Authors' original data

FIGURE 1: Number and causes of death of HIV-infected patients at Thembisa Hospital 2004-2006.

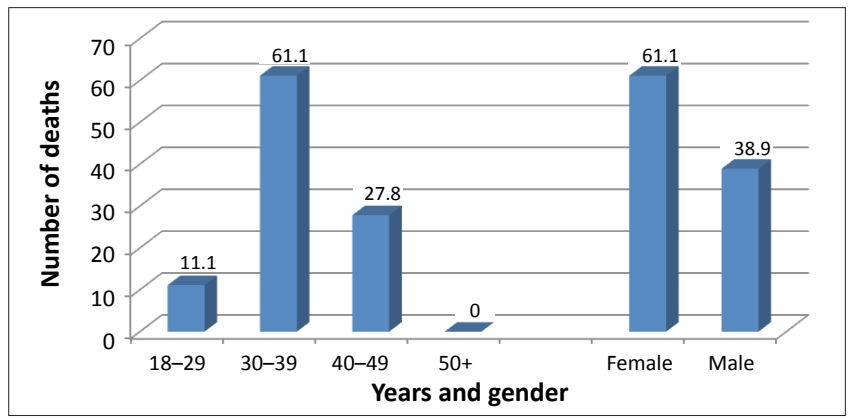

Source: Authors' original data

FIGURE 2: Demographic characteristics of HIV-infected patients that died at Thembisa Hospital 2004-2006.

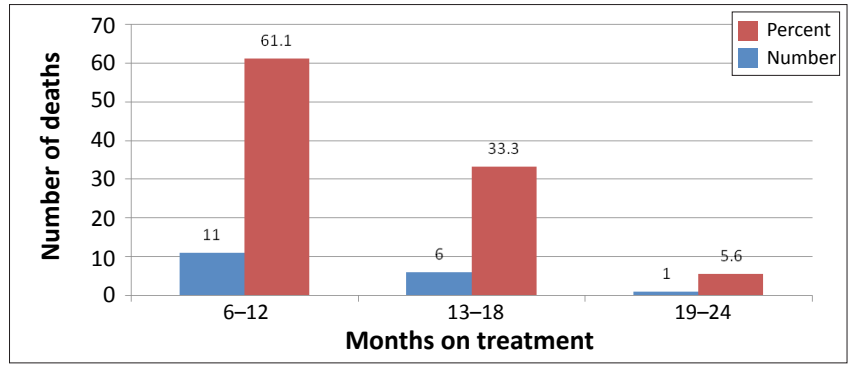

Source: Authors' original data

FIGURE 3: Trends of death per treatment period at Thembisa Hospital 20042006. 


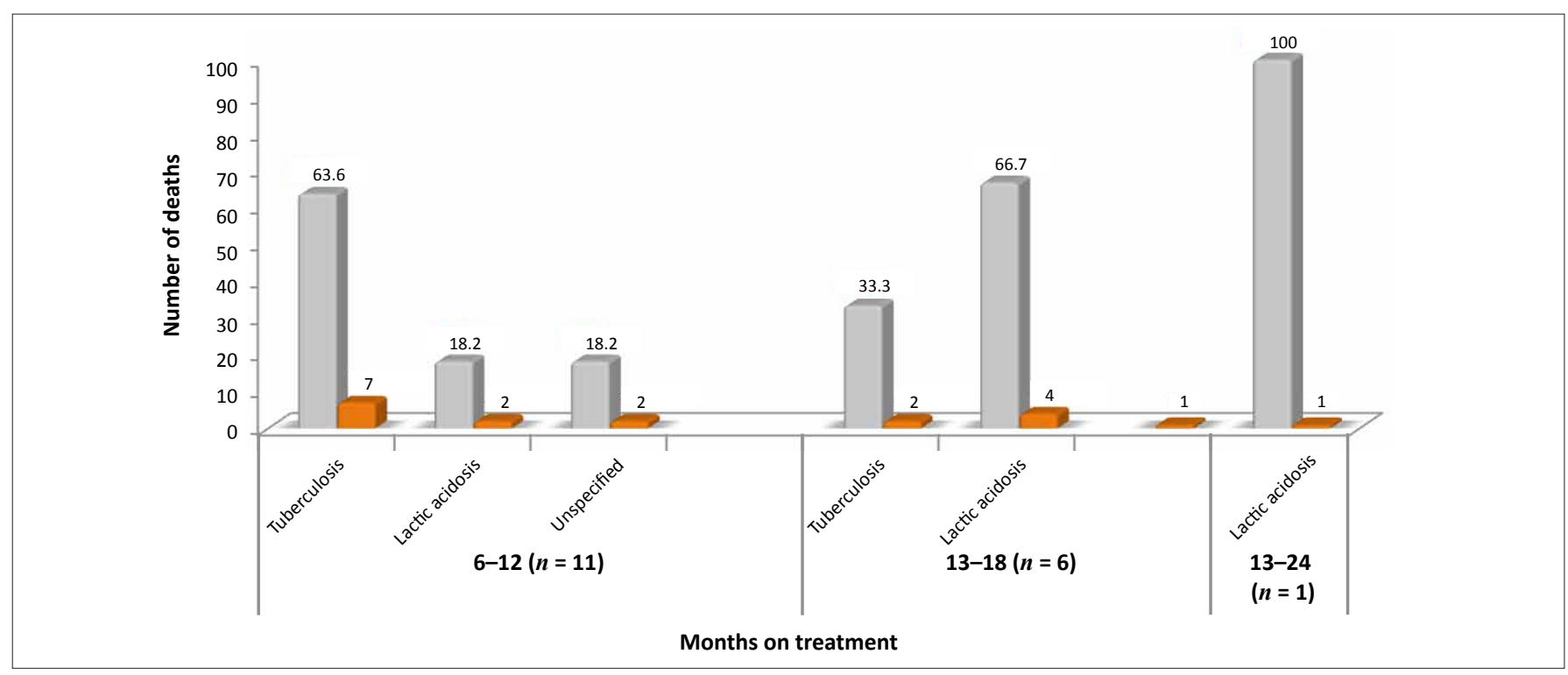

Source: Authors' original data

$n$, The number of patients.

FIGURE 4: Tuberculosis and lactic acidosis deaths per treatment period at Thembisa Hospital 2004-2006.

\section{Discussion}

The prevalence of adverse events documented was $82.1 \%$. This figure is comparable to the figure of $89 \%$ reported at another hospital from the same province. ${ }^{11}$ This finding suggests that health-care providers of antiretroviral therapy have been doing good work by recording the adverse effects noticed. It further corroborates the view that side effects are common during antiretroviral therapy in South Africa in accordance to reports elsewhere. . $^{12,13,14}$ The most common effects, skin rashes, peripheral neuropathy, and lactic acidosis have been consistently reported in patients taking the regimen containing nevirapine and/or stavudine. At the time of the study, almost all patients were prescribed the regimen that contained stavudine. The range of adverse effects documented was similar to that reported previously by other investigators. ${ }^{11,12,13,14}$ Moreover, the impact of adverse effects on adherence to antiretroviral treatment is well established, ${ }^{15,16}$ in this study, their impact on mortality has been assessed.

With regard to mortality, $3.6 \%$ had died during the 2 years covered by the study. This finding is consistent but lower than the figures reported in the literature..$^{17,18,19,20} \mathrm{In}$ fact, it has been reported that $8 \%-26 \%$ of patients die within the first year of antiretroviral treatment. ${ }^{21}$ Furthermore, the findings of this study concur with previous studies in that most deaths occurred during the initial months of treatment. ${ }^{22,23}$ Data from this study show that the majority of patients sought treatment when they were at an advanced clinical stage of the disease because $57 \%$ of them had been classified as WHO Stage 3 and Stage 4 patients (Table 3). This finding is consistent with previous reports about the influence of late initiation of antiretroviral treatement. ${ }^{13,4,17,23}$ In addition, $29.9 \%$ of them were afflicted by tuberculosis. Overall, $50 \%$ and $38.8 \%$ of deaths reported in this study were ascribed to tuberculosis and lactic acidosis respectively. Although the odds of dying were high for both conditions, because all patients that died had been severely immune-compromised, it is plausible that this situation also contributed to the deaths. Furthermore, although deaths ascribed to tuberculosis decreased from a majority $(63.6 \%)$ status by the end of the first year of treatment to zero towards the end of the second year, deaths ascribed to lactic acidosis increased during the same periods from $18.2 \%$ to $66.7 \%$ (Figure 3). This finding suggests that, although deaths caused by tuberculosis could be halted when tuberculosis is cured, the danger from lactic acidosis cannot be averted easily. Stavudine is known for its association with lactic acidosis, and consequently this finding lends support to the decision to remove stavudine as a component of the first line regimen in South Africa. 7,13,25,26 Indeed, as from April 2010, the new guidelines have replaced stavudine with tenofovir in the first line regimen. ${ }^{27}$ The rationale for this proposition is that lactic acidosis is insidious and produces ordinary symptoms such as nausea, vomiting, and abdominal pain. These symptoms may be overlooked by clinicians, which make it difficult for them to take the necessary steps to save patients' lives. The distribution of deaths by age showed that a number of deaths were recorded in the age group of 30-39 (66\%) followed by the age group $40-49(28 \%)$. No deaths were recorded in patients who were 50 years or older, which suggests that older patients may have had a better survival rate because of their self-efficacy, or because they started the treatment early enough, but the rationale for the enhanced survival could not be established in this study. ${ }^{21,22,24,25,26,27,28}$

In addition, because of limitations relating to the design of this cross-sectional study, it is unclear whether the $11.1 \%$ of deaths that were undetermined were caused by other infections, or adverse effects that were not documented. Similarly, it is not known whether the non-prescribed medicines taken by some patients could have contributed to the occurrence of adverse events; this has been reported. ${ }^{29}$ Further prospective studies, including reported data on adverse effects, are needed to 
assess the impact of the involvement of other non-prescribed medicines on the deaths attributed to side effects such as lactic acidosis. Previous studies demonstrated the need for such studies. ${ }^{7,17,29}$ Professional health-care workers play an important role in the provision of antiretroviral therapy, ${ }^{30}$ and as such there is a need to keep them updated on new developments and to train them on the implementation of pharmacovigilance concepts in their clinical practice.

\section{Conclusion}

In addition to tuberculosis, side effects in particular, lactic acidosis was the other main cause of death in patients treated at the study site. These findings suggest that patients who take regimens containing drugs that cause lactic acidosis should be closely monitored when the first complaints suggesting lactic acidosis, are reported or noticed.

\section{Acknowledgements}

We thank the nursing sisters of Thembisa Hospital for their kind assistance with the study.

\section{Competing interests}

The authors declare that they have no financial or personal relationships which may have influenced them inappropriately in writing this paper.

\section{Author contribution}

Both authors participated in the design of the study. M.M. (Center for Diseases Control) was the principal investigator, and was responsible for data management. M.N. (University of Limpopo) drafted the paper; both authors approved the final manuscript.

\section{References}

1. Coetzee D, Hildebrand K, Boulle A, Maartens G, Louis F, Labatala V, et al. Outcomes after two years of providing antiretroviral treatment in Khayelitsha, South Africa. AIDS. 2004;18:887-895. http://dx.doi.org/10.1097/00002030-200404090-00006 PMid:15060436

2. Bekker LG, Myer L, Orrell C, Lawn S, Wood R. Rapid scale-up of a communitybased HIV treatment service: programme performance over 3 consecutive years in Guguletu, South Africa. S Afr Med J. 2006;96:315-320. PMid:16670804

3. Wester CW, Kim S, Bussmann H, Avalos A, Ndwapi N, Peter TF, et al. Initial response to highly active antiretroviral therapy in HIV-1C-infected adults in a public sector treatment program in Botswana. J Acquir Immune Defic Syndr. 2005;40:336-343. http://dx.doi.org/10.1097/01.qai.0000159668.80207.5b

4. Palella FJ Jr, Delaney KM, Moorman AC, Loveless MO, Fuhre J, Satten GA, et al. Declining morbidity and mortality among patients with advanced human immunodeficiency virus infection. N Engl J Med. 1998;338:853-860. http:// dx.doi.org/10.1056/NEJM199803263381301, PMid:9516219

5. Detels R, Munoz A, McFarlane G, Kingsley LA, Margolick JB, Giorgi J, et al. Effectiveness of potent antiretroviral therapy on time to AIDS and death in men with known HIV infection duration. AIDS Cohort Study Investigators. JAMA. 1998;280:1497-1503

6. Hogg RS, Yip B, Kully C, Craib KJP, O'Shaughnessy MV, Schechter MT, et al. Improved survival among HIV-infected patients after initiation of triple-drug antiretrovira regimens. CMAJ. 1999;160(5):659-665. PMid:10102000, PMCid:1230111

7. Montessori V, Press N, Harris M, Akagi L, Montaner JSG. Adverse effects of antiretroviral therapy for HIV infection. CMAJ. 2004;170(2):395-397.
8. D’Arminio Monforte A, Lepri AC, Rezza G, Pezzotti P, Antinori A, Phillips AN, et al. Insights into the reasons for discontinuation of the first highly active antiretroviral therapy (HAART) regimen in a cohort of antiretroviral naïve patients. I.CO.N.A therapy (HAART) regimen in a cohort of antiretroviral naive patients. I.CO.N.A. 507. PMid:10780712

9. Lucas GM, Chaisson RE, Moore RD. Highly active antiretroviral therapy in a large urban clinic: risk factors for virologic failure and adverse drug reactions. Ann Intern Med. 1999;131:81-87. PMid:10419445

10. Carr A, Cooper DA. Adverse effects of antiretroviral therapy. Lancet. 2000;356:1423-1430. http://dx.doi.org/10.1016/S0140-6736(00)02854-3

11. Malangu N. Self-reported versus documented side effects of antiretrovira drugs in a sample of HIV-infected patients in Pretoria, South Africa. Toxicol Lett. 2006;164S:S1-S324.

12. Fellay J, Bousaker K, Ledergerber B, Bernasconi E, Furrer $H$, Battegay $M$, et al. Prevalence of adverse drug events associated with potent antiretrovira treatment: Swiss HIV cohort study. Lancet. 2001;358:1322-1327. http://dx.doi. org/10.1016/S0140-6736(01)06413-3

13. Kumarasamy MP, Balakrishnan K. Safety, tolerability and effectiveness of locally produced generic antiretroviral drugs in persons with HIV disease in Southern India. Int Cong Drug Ther HIV. 2002;6:298

14. Cantrell R, Chi B, Mulenag L, et al. Incidence and predictors of hepatotoxicity among patients receiving nevirapine (NVP)-containing antiretroviral therapy (ART) in Zambia [abstract WEPE0172]. Program and abstracts of the 16th International in Zambia [abstract WEPEO172]. Program and abstracts of the 16th International AIDS Conf.

15. Malangu N. Self-reported adverse effects as barriers to adherence to antiretroviral therapy in HIV-infected patients in Pretoria. SA Fam Pract. 2008;50(5):49.

16. Rougemont $M$, Stoll BE, Elia N, Ngang P. Antiretroviral treatment adherence and its determinants in Sub-Saharan Africa: a prospective study at Yaounde Central Hospital, Cameroon. AIDS Research and Therapy. 2009;6:21. http://dx.doi. org/10.1186/1742-6405-6-21, PMid:19821997, PMCid:2770068

17. Malangu N, Karamagi Y. Impact of adverse events of antiretroviral treatment on regimen change and mortality in Ugandan children. Afr J Prim Health Care Fam Med. 2010;2(1), Art. \#109, 4 pages. DOI: 10.4102/phcfm.v2i1.109

18. Wamalwa DC, Farquhar C, Obimbo EM, Selig S, Mbori-Ngacha DA, Richardson BA, et al. Early response to highly active antiretroviral therapy in HIV-1-infected Kenyan children. J Acquir Immune Defic Syndr. 2007;45:311-317. PMid:17356470

19. Obimbo EM, Mbori-Ngacha DA, Ochieng JO, Richardson BA, Otieno PA, Bosire R, et al. Predictors of early mortality in a cohort of human immunodeficiency virus type 1-infected African children. Pediatr Infect Dis J. 2004;23:536-543. http:// dx.doi.org/10.1097/01.inf.0000129692.42964.30, PMid:15194835

20. Reddi A, Leeper SC, Grobler AC, Geddes R, France KH, Dorse GL, et al. Preliminary outcomes of a paediatric highly active antiretroviral therapy cohort from KwaZuluNatal, South Africa. BMC Pediatr. 2007:7:13. http://dx.doi.org/10.1186/14712431-7-13, PMid:17367540, PMCid:1847430

21. Finkbeiner T, Luyirika E, Nabiddo L, Shinde S, Kilule E, Kasule K, et al. Antiretrovira therapy for HIV-infected children in Uganda, 2004-2005. Proceedings of the XVI International AIDS Conference; 2006 Aug 13-18; Toronto, Canada. Abstract WEPE0111.

22. Moore D, Liechty C, Ekwaru P, Were W, Mwima G, Solberg P, et al. Prevalence, incidence and mortality associated with tuberculosis in HIV-infected patients initiating antiretroviral therapy in rural Uganda. AIDS. 2007;21:713-719. http:// dx.doi.org/10.1097/QAD.0b013e328013f632, PMid:17413692

23. Braitstein $P$, Brinkhof MW, Dabis F, Schechter M, Boulle A, Miotti P, et al. Mortality of HIV-1-infected patients in the first year of antiretroviral therapy: comparison between low-income and high-income countries. Lancet. 2006;367:817-824.

24. Lawn SD, Harries AD, Anglarete X, Myer L, Wood R. Early mortality among adults accessing antiretroviral treatment programmes in sub-Saharan Africa. AIDS. 2008;22:1897-1908.

25. Kimani DK, Filen F, Nderitu M, Van Engelgem I, Suleh A, Zachariah R. Characteristics and outcomes of patients with symptomatic hyperlactatemia, on a first-line antiretroviral regimen of stavudine, lamivudine, and nevirapine in an urban district hospital setting in Kenya. XVIth International AIDS Conference. 2006 August 13-18. Toronto, Canada. Abstract WePe0150.

26. Geddes R, Knight S, Moosa MY, Reddi A, Uebel K, Sunpath H. A high incidence of nucleoside reverse transcriptase inhibitor (NRTI)-induced lactic acidosis in HIV-infected patients in a South African context. S Afr Med J. 2006;96:722-724. PMid:17019496

27. National Department of Health. The South African antiretroviral treatment guidelines 2010. [homepage on the Internet]. No date [cited 2011 May 28] Available from: http://www.doh.gov.za/docs/factsheets/guidelines/art.pdf

28. Silverberg MJ, Leyden W, Horberg MA, DeLorenze GN, Klein D, Quesenberry CP Jr. Older Age and the Response to and Tolerability of Antiretroviral Therapy. Arch Intern Med. 2007;167:684-691. http://dx.doi.org/10.1001/archinte.167.7.684, PMid:17420427

29. Malangu N. Self-reported use of traditional, complementary and over-thecounter medicines by HIV-infected patients on antiretroviral therapy in Pretoria, South Africa. Afr J Trad Complem. 2007;4(3):273-278.

30. Malangu N. Human health resources are key to HIV treatment in Africa. Brit Med J. 2006;333:98. http://dx.doi.org/10.1136/bmj.333.7558.98-a, PMid:16825241, PMCid:1489257 